\title{
Commentary
}

\section{A Groundbreaking Work Which Laid the Foundation for Mass Screening in Cervical Cytology in Japan}

\author{
Robert Y. Osamura
}

International University of Health and Welfare, Graduate School, Tokyo, and Department of Diagnostic Pathology, Nippon Koukan Hospital, Kawasaki, Japan

\section{Keywords}

Cervical cancer - Cervical cytology - Carcinoma in situ .

Atypical cells · Cancer staging · Cancer screening

\section{Abstract}

This commentary discusses the impact of a milestone article on the accuracy of cervical smears for detecting cancer back in the developmental and transforming era of the cytological detection of atypical and malignant cells. The study served in the establishment of cancer screening in Japan which has contributed greatly in decreasing mortality from cervical cancers.

๑) 2017 S. Karger AG, Basel

We discuss a milestone paper [1] from the Japanese Society of Clinical Cytology (JSCC) published in Acta Cytologica. We consider the article to be important for the following reasons:

1. This was an early, extensive study on the high accuracy of cervical cytology at a cancer hospital.

2. The JSCC was started in 1961 while this study was being carried out.

\section{KARGER}

(c) 2017 S. Karger AG, Basel

E-Mail karger@karger.com

www.karger.com/acy
3. Gynecologists were the founding members of the JSCC and the authors of the paper were contributing gynecologists from the Society.

4. The International Academy of Cytology (IAC) was started in 1957 during this study.

This milestone study [1] stated: "The vaginal aspiration smear was the only test used from 1952 to June 1957. But since July 1957, the scrape smear has been added. The scrape sample was prepared by scraping of the erosive surface in the ectocervix with a cotton swab."

"The staining method used is Papanicolaou's EA 36. This study utilized the five-class classification by Papanicolaou. Cases of Class IV and V were considered to be cancer, and cases of Class I and II noncancer, while cases of class III were considered to be false-positive."

And, regarding surgically resected materials: "Masubuchi divided Stage 0 into three subgroups: Stage $0-\mathrm{A}$, $0-B$, and $0-C$. The cases of Stage $0-A$ show carcinoma in situ-like findings by punch biopsy, but by thorough examination of the removed material no lateral invasion is found, but rather benign characteristics; those of Stage $0-\mathrm{B}$ show typical carcinoma in situ; and those of Stage $0-\mathrm{C}$ are suspected invasive." 


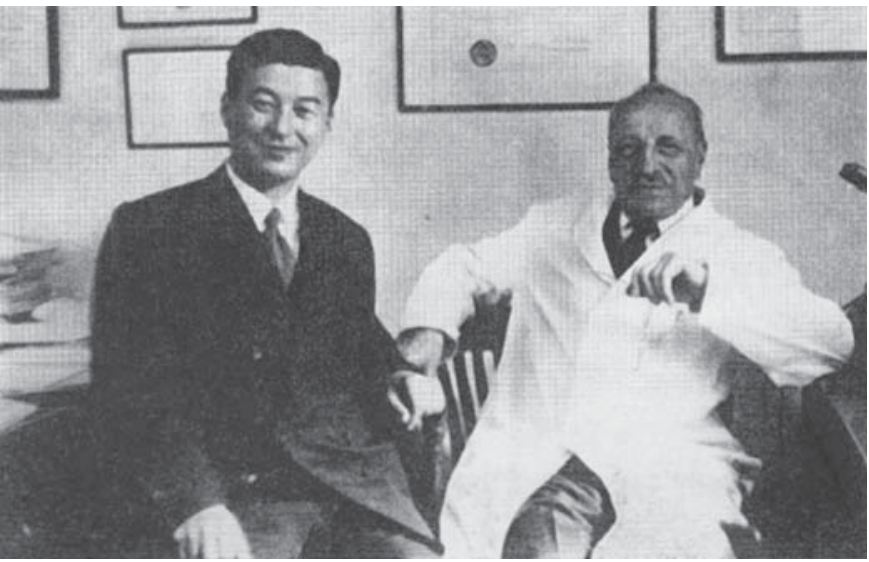

Fig. 1. Dr. Kazumasa Masubuchi and Dr. George Papanicolaou in the early days.

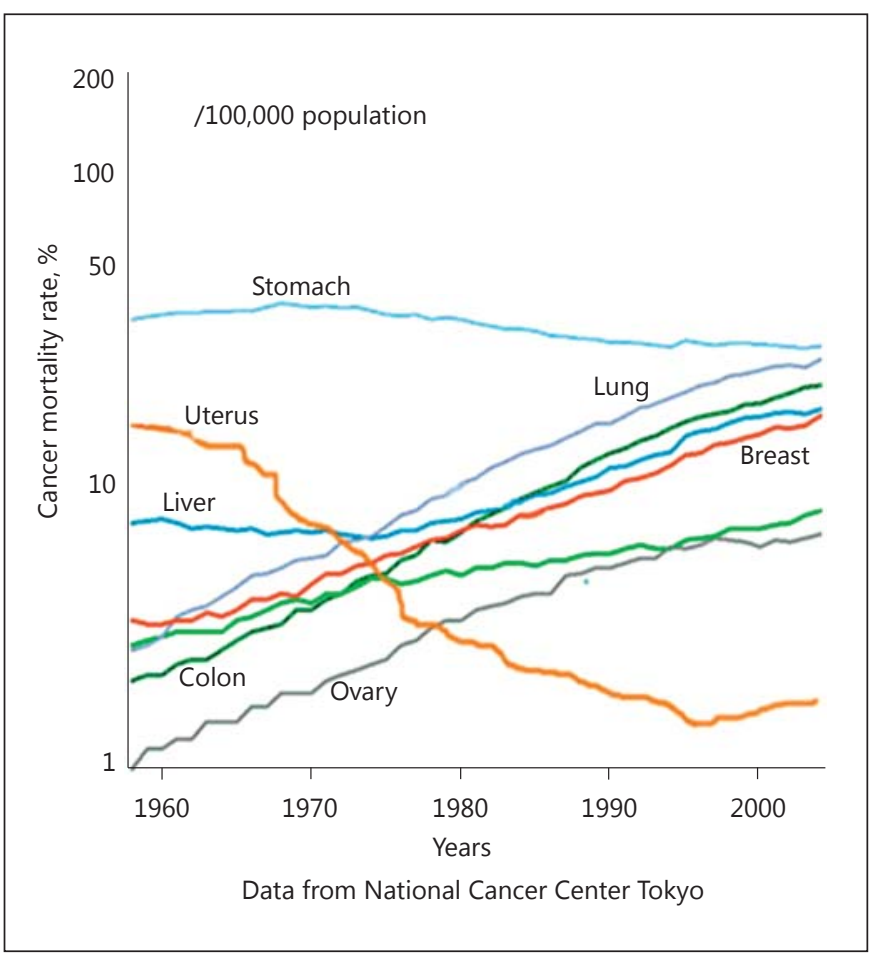

Fig. 2. The mortality rate of uterine/cervical cancer has markedly decreased in Japan.

"The number of carcinomas of the cervix diagnosed from 1952 to 1963 was 2,918, and the number of positive cases (i.e., class IV or Class V) detected by smear was 2,660 , so the smear was $91.2 \%$ accurate."
By means of Tables 1-6, the study demonstrated the high accuracy/correct diagnosis rate of smear findings in cancer and non-cancer groups (Table 1) and for cervical cancer staging (stages 0-IV; Table 2), the relationship between the stage of cervical cancer and the smear finding (Table 3), the frequency of class III-V smears in stage 0 (Table 4), the frequency of class III-V smears in "stage I" cervical carcinoma (Table 5), and the histologic findings in non-cancer cases with class III-V smears (Table 6).

Table 7 showed "the result of smear findings in the cases diagnosed atypical epithelium by biopsy during these six and half years" (i.e., July 1957 to December 1963). The authors emphasized that the high rate (54/143 cases, i.e., $37.8 \%$ ) of atypical epithelium showing class III, IV, or V by smear test is worthy of special attention.

They concluded: "Vaginal smear examinations were adopted as a routine practice in Japan in 1961. From 1961 to 1964 about 20,000 women were cytologically examined at 92 hospitals" (65 cases [0.5\%] were diagnosed as carcinoma of the uterus) [1].

This paper emphasized the role of cervical smears in cancer detection in Japan and served as a basis for the subsequent introduction of the cancer screening program.

\section{This Paper and the JSCC}

The JSCC is an academic society that promotes scientific research in clinical cytology and cytopathology and the application of research findings in clinical practice. The JSCC's beginnings date back to 1961. Modern cytological diagnosis began in 1928 with George Papanicolaou [2], whose technique of cervical smears became recognized as an effective method of diagnosing uterine cancer. The Gynecological Cytodiagnosis Discussion Group was formed in Japan in response to the creation of the International Academy of Gynecological Cytology in 1957. In 1961, the latter was renamed the IAC, to include advances in other fields and the former converted to the name JSCC. The study that is the subject of this commentary [1] was conducted during this period of transformation in the field of cytology in Japan (Fig. 1).

The JSCC has been instrumental in the early detection of cancers including cervical, lung, and breast cancers. In the course of the long history of the JSCC, its cervical cancer exams, in particular, have contributed significantly to reducing the fatality rate for uterine/cervical cancer (Fig. 2). 
Contributions by Drs. Masubuchi, Tenjin, and Fujii to Acta Cytologica

Of 50 contributions to PubMed, Dr. Masubuchi's study group has published a total of 7 papers $[1,3-8]$ in Acta Cytologica ([1] was the first paper he wrote in English); Dr. Tenjin's group a total 4 papers $[1,4,9,10]$; and Dr. Fujii has contributed 1 [1].

\section{The International Development of Cervical Cancer Detection and Cytology}

By the 1960s, cervical cytology screening and the basic concepts of gynecologic cytopathology were fairly well established in the USA. During the 1950s and early 1960s, several famous monographs and atlases were published.
At about this time, numerous articles describing both the cytologic manifestations of cervical carcinoma and its precursors also began to appear in the literature. These excellent publications summarize and illustrate the thencurrent state of knowledge in this field. They include: $\mathrm{Pa}-$ panicolaou's Atlas of Exfoliative Cytology [11] in 1954, Fluhmann's The Cervix Uteri and Its Diseases [12] in 1961, Graham's The Cytologic Diagnosis of Cancer [13] in 1963, and the first edition of Koss' Diagnostic Cytology and Its Histologic Bases [14] in 1961.

\section{Disclosure Statement}

The author has nothing to declare regarding this publication. 


\title{
The Detection of Cervical Cancer at Cancer Institute Hospital in Tokyo from 1952 to 1963
}

\author{
Kazumasa Masubuchi, M.D., Yoshio Tenjin, M.D., \\ Jun-Ichi FujII, M.D. \\ Deparlment of Gynecology, Cancer Institute Hospital, Nishi-Sugamo, Toshima-ku Tokyo, Japan
}

\section{INTRODUCTION}

The smear test is used in the Gynecology Department at the Cancer Institute in Tokyo as a screening test for the detection of female genital cancer. It has been applied to all out-patients as a routine method of detection of the disease since 1952.

The following report concerns the result of research from 1952 to 1963.

\section{Materials and Methons}

The vaginal aspiration smear was the only test used from 1952 to June 1957. But since July 1957, the scrape smear has been added. The scrape sample was prepared by scraping of the erosion surface in the ectocervix with a cotton swab. In cases having little or no change in the ectocervix, the endocervical smear was also taken. For postmenopausal women especially, great importance was placed on the examination of the endocervical scrape smear.

The staining method used is Papanicolaou's EA 36 .

This study used the five-class classification by Papanicolaou. Cases of Class IV and V were considered to be cancer, and cases of Class I and II noncancer, while cases of Class III were considered to be false-positive.

After a thorough examination was performed on the removed materials diagnosed as carcinoma in situ, i.e., Stage 0 , various gradings were provided according to the pathologic findings. Masubuchi divided Stage 0 into three subgroups: Stage 0-A, $0-\mathrm{B}$, and 0-C. The cases of Stage 0-A show carcinoma in situ-like findings by punch biopsy, but by thorough examination of the removed material no lateral invasion is found, but rather benign characteristics; those of Stage $0-B$ show typical carcinoma in situ; and those of Stage 0-C are suspected invasive.

\section{RESULTS}

Out of 49,996 patients examined during these 12 years, 3,612 cases $(7.2 \%)$ were found to be carcinoma, and 46,384 cases were non-cancer.

Presented at the Second International Congress of Exfoliative Cytology, Paris, France, 1965.
As shown in Table 1, $90.4 \%$ of the cases diagnosed as cancer yielded positive smears, and $98.7 \%$ of the negative cases were correctly diagnosed. Histologic diagnosis by biopsy was adopted for the final determination of the disease.

In Japan, most of female genital cancer is carcinoma of the cervix. Therefore, the main interest of the smear test is cancer of the cervix. The number of carcinoma of the cervix diagnosed from 1952 to 1963 was 2,918 , and the number of positive cases (i.e., Class IV or Class V) detected by smear was 2,660 , so the smear was $91.2 \%$ accurate. As shown in Table 2, the results obtained by combined tests of vaginal aspiration and scrape smear for six and a half years showed higher accuracy in cases in the early stage: $69.6 \%$ in Stage $0,84.9 \%$ in Stage I, and $96.4 \%$ in Stage II.

Considering the relationship between clinical stages and Papanicolaou's classification in 2,149 cases with cancer of the cervix, as shown in Table 3 , $91.5 \%$ of all cases are in Class IV and V, $4.7 \%$ in Class III, and $3.8 \%$ in Classes I and II, that is, false-negative. If Class III is included in cancer cases, the percentage is raised to $96.2 \%$. Therefore, the correct diagnosis was $84.8 \%$ in Stage $0,94.0 \%$ in Stage I and $99 \%$ in Stages II, III and IV. In Class III, the rate is $15.2 \%$ in Stage $0,9.0 \%$ in Stage I and rare in Stages II, III and IV. One cannot disregard the fact that some cases in Stage 0 and early Stage I could be classified as Class III by smear test.

After the three sub-groupings ( $0-A, 0-B, 0-C)$ for the cases diagnosed as carcinoma in situ were provided, they were compared with smear findings on the cases from 1960 to 1963 . The results of the cases diagnosed as Class III, IV and V are shown in Table 4. In Stage 0-A, $42.9 \%$ were Class III, whereas in both Stages $0-\mathrm{B}$ and $0-\mathrm{C}$ only $11.5 \%$ were Class III. On the other hand, in Classes IV and $\mathrm{V}$ the percentage is as high as 88.5. The cases in Stage I were divided into early invasive and definitely invasive, and the frequency of appearance of Class III in both groups is summarized in Table 5. In the early invasive group, the rate of appearance of Class III was $24.5 \%$ and that of Classes IV and V was $75.5 \%$; in the definitely invasive group, the rate of appearance of Class 
TABLE 1. Over-All Results of Smear Findings

Cancer Institute Hospital, Tokyo (1952-1963)

\begin{tabular}{lrrrrrrrrr}
\hline & \multicolumn{3}{c}{ 1952-June 1957 } & \multicolumn{2}{c}{ June 1957-Dec. 1963 } & & \multicolumn{2}{c}{ Total } \\
\cline { 2 - 10 } & $\begin{array}{l}\text { Number of } \\
\text { patients }\end{array}$ & $\begin{array}{c}\text { Correct } \\
\text { diagnosis }\end{array}$ & $\%$ & $\begin{array}{c}\text { Number of } \\
\text { patients }\end{array}$ & $\begin{array}{c}\text { Correct } \\
\text { diagnosis }\end{array}$ & $\%$ & $\begin{array}{c}\text { Number of } \\
\text { patients }\end{array}$ & $\begin{array}{c}\text { Correct } \\
\text { diagnosis }\end{array}$ & $\%$ \\
\hline Cancer & 1,389 & 1,262 & 90.9 & 2,223 & 2,007 & 90.3 & 3,612 & 3,269 & 90.4 \\
Non-cancer & 11,268 & 10,981 & 97.5 & 35,116 & 34,793 & 99.1 & 46,384 & 45,774 & 98.7 \\
\hline
\end{tabular}

TABLE 2. Over-all Results of Smear Findings in Staging of Carcinoma of the Cervix (1952-1963)

\begin{tabular}{rrrrrrrrrrr}
\hline & \multicolumn{3}{c}{ 1952-June 1957 } & \multicolumn{3}{c}{ June 1957-Dec. 1963 } & \multicolumn{2}{c}{ Total } \\
\cline { 2 - 10 } Stage & $\begin{array}{c}\text { Number of } \\
\text { patients }\end{array}$ & $\begin{array}{c}\text { Correct } \\
\text { diagnosis }\end{array}$ & $\%$ & $\begin{array}{c}\text { Number of } \\
\text { patients }\end{array}$ & $\begin{array}{c}\text { Correct } \\
\text { diagnosis }\end{array}$ & $\%$ & $\begin{array}{c}\text { Number of } \\
\text { patients }\end{array}$ & $\begin{array}{c}\text { Correct } \\
\text { diagnosis }\end{array}$ & $\%$ \\
\hline 0 & 40 & 20 & 50.0 & 184 & 128 & 69.6 & 224 & 148 & 66.1 \\
I & 153 & 123 & 77.4 & 511 & 434 & 84.9 & 664 & 557 & 83.9 \\
II & 282 & 270 & 95.7 & 691 & 666 & 96.4 & 973 & 936 & 96.2 \\
III & 237 & 230 & 97.0 & 684 & 664 & 97.1 & 921 & 894 & 97.1 \\
IV & 57 & 50 & 87.7 & 79 & 75 & 94.9 & 136 & 125 & 91.9 \\
\hline Total & 769 & 693 & 90.1 & 2149 & 1967 & 91.5 & 2918 & 2660 & 91.2 \\
\hline
\end{tabular}

TABLE 3. Relation Between Stage of Cancer of the Cervix Uteri and Smear Findings Cancer Institute Hospital, Tokyo (July 1957-Dec. 1963)

\begin{tabular}{|c|c|c|c|c|c|c|c|c|c|c|c|c|}
\hline & \multicolumn{2}{|c|}{ Stage 0} & \multicolumn{2}{|c|}{ Stage I } & \multicolumn{2}{|c|}{ Stage II } & \multicolumn{2}{|c|}{ Stage III } & \multicolumn{2}{|c|}{ Stage IV } & \multirow{2}{*}{ Total } & \multirow[b]{2}{*}{$\%$} \\
\hline & $\begin{array}{c}\text { Number of } \\
\text { patients }\end{array}$ & $\%$ & $\begin{array}{l}\text { Number of } \\
\text { patients }\end{array}$ & $\%$ & $\begin{array}{c}\text { Number of } \\
\text { patients }\end{array}$ & $\%$ & $\begin{array}{l}\text { Number of } \\
\text { patients }\end{array}$ & $\%$ & $\begin{array}{c}\text { Number of } \\
\text { patients }\end{array}$ & $\%$ & & \\
\hline Class IV, V & 128 & 69.6 & 434 & 85.0 & 666 & 96.4 & 664 & 97.1 & 75 & 98.6 & 1967 & 91.5 \\
\hline Class III & 28 & 15.2 & 46 & 9.0 & 16 & 2.3 & 10 & 1.5 & 2 & 0.7 & 102 & 4.7 \\
\hline $\begin{array}{l}\text { (Class III- } \\
\text { IV-V }\end{array}$ & 156 & 84.8 & 480 & 94.0 & 682 & 98.7 & 674 & 98.6 & 77 & 99.3 & 2069 & $96.2 \mathrm{I}$ \\
\hline Class I, II & 28 & 15.2 & 31 & 6.0 & 9 & 1.3 & 10 & 1.4 & 2 & 0.7 & 80 & 3.8 \\
\hline Total & 184 & & 511 & & 691 & & 684 & & 79 & & 2149 & \\
\hline
\end{tabular}

TABLE 4. Frequency of Class $I I I-V$ Smears in Stage 0 (1960-1963)

\begin{tabular}{|c|c|c|c|c|c|}
\hline & \multicolumn{2}{|c|}{ Class III } & \multicolumn{2}{|c|}{ Class IV, V } & \multirow{2}{*}{$\frac{\text { Ttotal }}{14}$} \\
\hline Stage $0-A$ & 6 & $42.9 \%$ & 8 & $57.1 \%$ & \\
\hline $\begin{array}{l}\text { Stage 0-B } \\
\text { Stage 0-C }\end{array}$ & $\left.\begin{array}{l}3 \\
4\end{array}\right\} 7$ & $11.5 \%$ & $\left.\begin{array}{l}34) \\
20\end{array}\right\}^{54}$ & $88.5 \%$ & $\left.\begin{array}{l}37 \\
24\end{array}\right\} 61$ \\
\hline
\end{tabular}

III was $8.5 \%$, while in Classes IV and V it was $91.5 \%$.

From July 1957 to 1963,496 cases were diagnosed by biopsy as nonmalignant, but were placed in Classes III, IV, and V by smear findings. This is only $1.4 \%$ of the total 35,116 non-malignant cases examined during the experimental period (as shown in Table 6). Out of 496 cases, 14.7\% were histologically diagnosed as atypical epithelium, but the final decision as to whether the smear test was correct or not should be made after the follow-up study. 
TABle 5. Frequency of Class $I I I, I V, V$ Smears in "Stage I" Carcinoma of the Cervix (1960-1963)

\begin{tabular}{lrrrr}
\hline & $\begin{array}{c}\text { Class } \\
\text { III }\end{array}$ & $\%$ & $\begin{array}{c}\text { Class } \\
\text { VV, }\end{array}$ & $\%$ \\
\hline $\begin{array}{l}\text { Squamous cell carci- } \\
\quad\end{array}$ & & & & \\
$\quad$ noma & 12 & 24.5 & 37 & 75.5 \\
Early invasive & 19 & 8.5 & 205 & 91.5 \\
Definite invasive & 19 & & 10 & \\
Adeno-carcinoma & 2 & & & \\
\hline
\end{tabular}

TABle 6. Histrologic Findings in Non-Cancer Cases with Class III, IV, V Smears (July 1957-Dec. 1963)

\begin{tabular}{|c|c|c|c|c|c|}
\hline & Class III & $\begin{array}{c}\text { Class } \\
\text { IV }\end{array}$ & Class V & Total & $\%$ \\
\hline Atypical epith. & 41 & 15 & 17 & 73 & 14.7 \\
\hline $\begin{array}{l}\text { Cervicitis, epi- } \\
\text { dermoid } \\
\text { metaplasia }\end{array}$ & 246 & 43 & 46 & 335 & 67.5 \\
\hline Miscellaneous & 72 & 7 & 9 & 88 & 17.8 \\
\hline
\end{tabular}

Table 7 shows the result of the smear findings in the cases diagnosed atypical epithelium by biopsy during these six and a half years. Out of 143 cases of atypical epithelium, 54 cases (37.8\%) showed Class III, IV or V by smear test. This high rate should be noticed with great attention.

\section{Discussion}

Today the final decision of cancer is based on biopsy using histologic criteria. But it is important to follow up the cases in which the smear showed false-positive, not leaving them as erroneous. There were many cases in such a group in which cancer developed later.

\section{SUMMARY}

Vaginal smear examinations were adopted as a routine practice in Japan in 1961. From 1961 to 1964 about 20,000 women were cytologically examined at 92 hospitals. There were 65 cases $(0.5 \%)$ diagnoses of carcinoma of the uterus.

\section{REFERENCES}

1. Masubuchi, K.: On early diagnosis of cancer of the cervix uteri. J. Jap. Obst. \& Gynec. Soc. (Japanese) 11:567-586, 1959.

2. Masubuchi, K., et al: Detection of the cancer of the cervix uteri by follow-up study. Cancer Clinic( Japanese) 5:505-512, 1959.

3. Masubuchi, K., et al.: On the cytologic diagnosis in cancer of the cervix uteri. Cancer Clinic (Japanese) 5: 599-605, 1959.

4. Masubuchi, K. and Suzuki, T.: The value and the limit of smear test. World of Obstet. \& Gynec. (Japanese) 13:948-954, 1961.

TABLE 7. Histologic Abnormal Findings and its Smear Findings

(July 1957-Dec. 1963)

\begin{tabular}{lcccccc}
\hline \multicolumn{1}{c}{ Histologic findings } & Class I & Class II & Class III & Class IV & Class V & Total \\
\hline Atypical epith. hyperplasia & 59 & 21 & 28 & 15 & 6 & 129 \\
Basal-cell hyperplasia & 8 & 1 & 2 & 2 & 14 & 14 \\
& & & & 54 & $37.8 \%$ & \\
\hline
\end{tabular}

\section{References}

1 Masubuchi K, Tenjin Y, Fujii J: The detection of cervical cancer at Cancer Institute Hospital in Tokyo from 1952 to 1963. Acta Cytol 1967; 11:32-34.

2 Siang Yong T, Tatsumara Y: George Papanicolaou (1883-1962): discoverer of the Pap smear. Singapore Med J 2015;56: 586-587.

3 Masubuchi K: Significance of the role of cytology in population screening of cancers. Acta Cytol 1975; 19:334-336.

4 Masubuchi K, Kubo H, Tenjin Y, Ono M, Yamazaki M: Follow-up studies by cytology on cancer of the cervix uteri after treatment. Acta Cytol 1969;13:323-326.

5 Masubuchi S Jr, Nagai I, Hirata M, Kubo H, Masubuchi K: Cytologic studies of malignant melanoma of the vagina. Acta Cytol 1975;19: 527-532.
6 Fujimoto I, Masubuchi S, Miwa H, Fukuda K, Yamaguchi S, Masubuchi K: Psammoma bodies found in cervicovaginal and/or endometrial smears. Acta Cytol 1982;26:317-322.

7 Hirai Y, Chen JT, Hamada T, Fujimoto I, Yamauchi K, Hasumi K, Masubuchi K, Sakamoto A: Clinical and cytologic aspects of primary fallopian tube carcinoma. A report of ten cases. Acta Cytol 1987;31:834-840.

8 Fujimoto I, Hirai Y, Hasumi K, Masubuchi K, Osamura Y: The value of epithelial membrane antigen in the diagnosis of ovarian tumors. Acta Cytol 1990;34:549-554.

9 Tenjin Y, Sugishita T, Yamamoto K: Automated cytoscreening system using $16 \mathrm{~mm}$ roll film. Acta Cytol 1977;21:276-286.
10 Tenjin Y, Yamamoto K, Sugishita T, Igarashi Y: Basic studies on repair, especially histology, cytology and microspectrophotometry of DNA contents. Acta Cytol 1979;23:245-251.

11 Papanicolaou GN (ed): Atlas of Exfoliative Cytology. Cambridge, Harvard University Press, 1954

12 Fluhmann CF (ed): The Cervix Uteri and Its Diseases. Philadelphia, W.B. Saunders, 1961

13 Graham RM (ed): The Cytologic Diagnosis of Cancer, ed 2. Philadelphia, W.B. Saunders, 1963.

14 Koss LG, Melamed MR (eds): Koss' Diagnostic Cytology and Its Histopathologic Bases. Philadelphia, Lippincott Williams \& Wilkins, 1961. 